\title{
Triple-rigorous storytelling: A PI's reflections on devising case study methods with five community-based food justice organizations
} \section{FoodDignity}

\author{
Christine M. Porter* \\ University of Wyoming
}

Submitted February 25, 2018 / Revised May 10 and June 5, 2018 / Accepted June 5, 2018 /

Published online July 18, 2018

Citation: Porter, C. M. (2018). Triple-rigorous storytelling: A PI's reflections on devising case study methods with five community-based food justice organizations. Journal of A griculture, F ood Systems, and Community D evelopment, 8(Suppl. 1), 37-61. https:/ / doi.org/ 10.5304/ jafscd.2018.08A.008

Copyright ( 2018 by the Author. Published by the Lyson Center for Civic Agriculture and Food Systems. Open access under CC BY license.

\begin{abstract}
Case study research provides scholarly paths for storytelling, with systematic methodological guides for achieving epistemological rigor in telling true stories and deriving lessons from them. For documenting and better understanding work as complex as community organizing for food justice, rigorous storytelling may proffer one of the most suitable research methods. In a five-year action-research project called Food D ignity, leaders of five food justice community-based organizations (CBO s) and academics at four universities collaborated to develop case studies about the work of the five $\mathrm{CBO}$ s. In this reflective essay, the project's principal investigator reviews methods used in other food justice case studies and outlines the case study methods used in Food Dignity. She also
\end{abstract}

* Christine M. Porter, Associate Professor and Wyoming Excellence Chair of Community and Public Health; Food Dignity Principal Investigator; Division of Kinesiology \& Health, College of Health Sciences, University of Wyoming; 1000 East University Avenue, D epartment 3196; Laramie, WY 82071 USA; christine.porter@uwyo.edu recounts lessons learned while developing these methods with collaborators. The community coinvestigators show her that telling true stories with morals relating to justice work requires three kinds of methodological rigor: ethical, emotional, and epistemological.

W ant a different ethic? Tell a different story.

- Thomas King, The T ruth A bout Stories (2005)

\section{Keywords}

Case Studies; Food Dignity; Research Methods

\section{Funding Disclosure}

Food Dignity (http:/ / www.fooddignity.org) was supported by Agriculture and Food Research Initiative Competitive G rant no. 2011-68004-30074 from the U.S. D epartment of Agriculture's National Institute of Food and Agriculture.

\section{Contributors and Supporting Agencies}

Blue Mountain Associates; Feeding Laramie Valley; Whole Community Project; East New York Farms!; Dig D eep Farms; University of Wyoming; Cornell University; and the U.S. D epartment of Agriculture National Institute of Food and Agriculture. 


\section{Introduction}

Some of the social theories and research methods I studied as a Ph.D. student seemed so intuitively obvious that academics claiming them, and often disguising them with unintuitive monikers, annoyed me. I would joke that I was using "the walking method of pedestrian theory." I would employ that simple phrase for complex reasons. I felt it mocked academic exclusion via discursive obfuscation or co-optation of common wisdom (such as knowing how to walk). Y et I hoped it still honored the nearly infinite complexity of understanding and changing human society (which is at least as complex as understanding how those with able bodies walk, and how that ability can sometimes be recovered when it is lost). It is this scale of complexity that social science research aims to help understand and improve, including tackling the most wicked of social problems. For example, how do, can, and should U.S. communities build community-led food systems that generate sustainable food security for all? These are the questions we $\mathrm{w}^{1}$ posed in a community-university action, research, and education project that we called F ood D ignity, for which I served as the project director and principal investigator (PI).

The opening paragraphs of our project application to USD A National Institute of Food and Agriculture (USD A NIFA) invoked the journeys taken by the five community-based organizations (CBO s) who had agreed to partner in Food Dignity. It also outlined the journey we proposed to take together over the next five years:

Community and social movements for food justice and sustainability suggest paths to an alternative, much brighter future, and they are making these paths by walking. In this integrated research, extension, and education project, we propose to trace the paths taken by five US communities and to collaborate in mapping and traveling the most appropriate and effective roads forward for creating sustainable community food systems (SCFS) for food security (FS).

${ }^{1}$ I use "our" and "we" in this paper to denote the dozens of community- and university-based co-investigators in the Food
O ur project title, "Food Dignity," signals both our ethical stance that human and community agency in food systems is an end in itself and our scientific hypothesis that building civic and institutional capacity to engage in SCFS for FS action will improve the sustainability and equity of our local food systems and economies. (Porter, Food Dignity proposal narrative, 2010)

Starting in April 2011, we were awarded US $\$ 5$ million for five years (which we extended to seven) to complete our proposed work. Using case study methods with the five $\mathrm{CBO}$ s was our primary approach to answering our triad of do, can, and should questions mentioned above.

In this essay, I share and reflect on my journey of developing and implementing these case methods with the Food Dignity team. This is partly a traditional methods paper, which summarizes our data gathering and analysis approaches. I embed that within an autoethnographic meta-methods paper, addressing the process of devising these methods while striving to meet ethical, epistemological, and emotional standards of rigor in our case study research. This "triple-e" rigor is what I mean by rigorous storytelling. Mentors, friends, students, and partners in Food Dignity generously tried to teach me how to do it and to do it with me. Here, I trace my journey of learning to try to collaboratively tell true and important stories about community-led work for food justice.

\section{Case Study Research Methods}

As an academic trained in western forms of science, I think of research as using systematic methods to generate new knowledge or understanding. According to indigenous research methods scholar Shawn Wilson, "Research is a ceremony... The purpose of any ceremony is to build stronger relationships or bridge the distance between our cosmos and us" (Wilson, 2008, p. 137). I have strived to bridge the distance between these research paradigms via rigorous, participatory, and ethically driven storytelling methods.

Dignity collaboration. 
Postmodern philosopher Lyotard (1979/ 1984) calls narrative "the quintessential form of customary knowledge" (p. 19), an idea which contrasts with western notions of scientific knowledge. However, by using systematic methods to document and develop true stories, researchers claim the scientific research mantle for case study narratives.

That said, as one scholar laments, "Regretfully, the term 'case study' is a definitional morass." He offers the following definition of 'case study': "an intensive study of a single unit for the purpose of understanding a larger class of (similar) units" (Gerring, 2004, p. 341-342). O ne aspect that he and three oft-cited case study methodologists (Merriam, 1998; Stake, 1995; Y in, 2009) agree on is that case studies are "bounded." For example, in Food Dignity, our primary case studies are bounded by the work of the five food justice CBOs.

As part of my dissertation work at Comell University, I developed case studies with three community-based childhood obesity prevention projects in the U.S. northeast (Porter, 2013). I employed common sense, I thought, my "walking method of pedestrian theory," in immersing myself in each case using multiple approaches. I was inspired by social science method guides (Flyvbjerg, 2001; Maxwell, 2005), worked under broader philosophical influences (including Foucault, 1972/ 1980, 1981; Habermas, 1981/ 1984; Lyotard, 1979/ 1984; McD onald, 2004; Sandoval, 2000; L. T. Smith, 1999), and consulted academic guides on several forms of qualitative data gathering and analysis. However, when it came time to write the case study chapter of my dissertation, this all seemed unconvincing to cite as a case study method since none of these were specifically case method references. In a semipanic, I read Stake's The A rt of C ase Study Research (1995), Merriam's 1998 guide, and Yin's $4^{\text {th }}$ edition of C ase Study Research: D esign and M ethods (2009). In a technical sense, Y in's guide closely mirrored the approach I had been taking. I claimed, almost entirely posthoc, that I had employed his case study methods.

Though his approach has been critiqued for being too reductive and positivist (Bartlett \& Vavrus, 2017; Y azan, 2015), Y in provides a highly practical and granular guide to case methods. He defines and describes case studies as follows:

1. A case study is an empirical inquiry that

- investigates a contemporary phenomenon in depth and within its real-life context, especially when

- the boundaries between phenomenon and context are not clearly evident.

2. The case study inquiry

- copes with the technically distinctive situation in which there will be many more variables of interest than data points, and as one result

- relies on multiple sources of evidence, with data needing to converge in a triangulating fashion, and as another result

- benefits from the prior development of theoretical propositions to guide data collection and analysis (Y in, 2009, p. 18).

Y in also outlines why case study methods are well suited to answering "how" and "why" questions and for understanding complex and current events (Y in, 2009, pp. 8-9). He suggests that these methods offer the most promising research approach when investigator "control of behavioral events" is not possible and when the "goal will be to expand and generalize theories (analytic generalization) and not to enumerate frequencies (statistical generalization)" (Y in, 2009, p. 15).

These parameters and Yin's definition apply to community-based food system and food justice work. Therefore, like many other researchers doing work about community food system and food justice projects, activities, and organizations, I proposed to use case study methods in Food Dignity. Continuing the mostly traditional methods part of this paper, next I review previous relevant case study research and share the case methods we used in Food Dignity.

\section{Case Study Methods Used with Food Justice CBOs in the Anglophone Global North}

NIFA issued the call for proposals that ultimately funded the Food D ignity project because so little about the extensive work of U.S. CBO s dedicated to creating food security and sustainability had been codified in writing, particularly in academic 
literature (USD A NIFA, 2010). Since then, the body of empirical literature about community-led food security or justice work has been growing; though, it is arguably still short of being proportional to the problems that the work is tackling.

Much of this research has been bounded by a focus on one activity, campaign, or project, as opposed to on the work of a community organization (which would be doing multiple such activities, campaigns, and/ or projects over time and with paid organizing staff). In the global North, this includes case studies of community gardens (e.g., Hallsworth \& Wong, 2015; Hou, Johnson, \& Lawson, 2009; Thrasher, 2016), mobile food markets (e.g, Robinson, Weissman, Adair, Potteiger, \& Villanueva, 2016), communitysupported agriculture (CSA) schemes (e.g., Cox, Kneafsey, Holloway, D owler, \& Venn, 2014; Hinrichs \& Kremer, 2002; Kato, 2013), activist campaigns (e.g., Alkon \& G uthman, 2017; Ballamingie \& Walker, 2013), and farmers markets (e.g., Alkon, 2007; Lawson, D rake, \& Fitzgerald, 2016). All of these studies provide descriptive cases and most present at least partial answers to questions about who does the activity, how and why, to what ends, and/ or who benefits from it.

A few studies have taken on much wider boundaries to examine local food movements within geographical borders as cases. Wekerle (2004) examines the movement in Toronto, Canada, to identify social movement strategies and lessons for food justice more generally. His methods are not specified. At another extreme for both specificity of method and breadth of scope is a book by Alan Hunt (2015), which compares and contrasts cases of British and U.S. food movements to answer questions about governance, civic engagement, and policy change in each. Epistemologically, Hunt's study offers a high standard for rigor and transparency in case study methods about food movements. He takes full advantage of the book-length format to do so, including sharing lists of his interviews (26) and field participation and observations (56). Hunt also characterizes the circa 1100 documents he analyzed and how he analyzed

2 This excludes Food Dignity-related publications and many food-justice-movement-related case studies that are not here them. In the conclusion, he advocates for "scrutiny of whether the academic publications [about food movement work] are rooted in primary evidence or formed from academic discourse" (Hunt 2015, p. 217). Another geographic example is Meenar and Hoover's (2012) case study analyzing how much community gardens and urban farms in Philadelphia offer viable solutions for food insecurity. In addition to traditional interview and observation case study methods, they use surveys and geographic information system (GIS) mapping tools.

A 2006 review of alternative food network (AFN) case study research in Europe (they identify eight studies, all of which are about producers or producer cooperatives) notes that "whilst individually these papers provide interesting accounts of specific AFNs," the work as a whole "tells us little about the population of AFS or the transferability of the conclusions from these often highly localized case studies" (Venn et al., 2006, p. 253). Methodologically, the authors also complain that the methods and reasons behind case selection are often not specified and that reflection on their wider relevance is missing. The methods used in a recent study addressing the role of food banks in U.S. community food systems illustrate a systematic approach to case selection designed to generate transferable results. The authors began their research with a national survey of food banks, drawing primarily from Feeding America's supply network, and then selected 15 operations for deeper case studies (Vitiello, Grisso, Whiteside, \& Fischman, 2015).

Case study research where the boundary (or unit of analysis) is a community-based food justice organization is very limited. This was our unit of analysis for the Food Dignity project: "Community" conscribed by hyperlocal geographic boundaries (at most a county or reservation) and "based" meaning the organization heavily includes leadership and other key stakeholders from within those boundaries. To date, I have identified 11 peer-reviewed publications (see Table 1) that substantially share both case study methods and empirical results about food justice CBO s. ${ }^{2}$ The

for one of two reasons. One, I am sure that there are some that I simply did not find in my review; this paper provides 
authors of these publications applied standard case study methods: collecting documents, interviews, and first-person observation data from and about the "case" CBO; analyzing these data inductively for emergent themes; analyzing these data deductively with their research questions and/ or theoretical framework in mind; providing at least a few paragraphs that tell the story of the case; and then concluding with a summary of themes and at least provisional answers to their research questions. Some also specify member checking.

In addition, a project called Community and Regional Food Systems (http:/ / www.communityfood.org) released an edited book about their work in 2017. That project had the same timeline and USD A NIFA funding stream as Food D ignity and their team had also proposed to do case study research about community-based food justice work and organizations. However, in the preface, the editors describe their proposed plans for case study research as a "nonstarter." They write, "Although our proposal was based on participatory research methods, it was apparent before we officially began that our community partners did not want to be studied" (Ventura \& Bailey, 2017, p. 3). Perhaps as a result, most chapters do not describe the data or methods used.

L iterature L essons for O ur C ase Study D evelopment Almost every example of food justice-related case study research reviewed here has been published after we began our work in Food D ignity. However, that body of work has influenced my thinking and feeling about our own rigorous storytelling approaches in several ways that I summarize here and elaborate upon in the rest of this essay. This includes:

- Committing even more deeply to our approach of collecting extensive data and using multiple inductive methods for

foundations for a (needed!) systematic literature review in this arena but is not one on its own. Two, I excluded many potential candidates because methods were not described and/ or the central case focus was not a food justice CBO. For example, some case studies focus on a singular program, collaboration or activity (e.g., a community garden, a food analysis, per Hunt's warning about remaining rooted in primary evidence rather than abstract academic discourse. We remind ourselves to avoid what I call "handwaving" (i.e., making knowledge claims without rigorous empirical substantiation).

- Feeling reassured about the rigor, relevance, and guiding ethics of our case study research methods and outcomes. We used the methods outlined in Table 1, and more, for all five cases over more than five years.

- Asking narrower research questions of our data, including potentially asking some of the same questions posed in previous studies to examine the transferability of their conclusions.

- Being more explicit about how and why we chose to do these case studies with these five CBO s, as well as how transferable our findings might be, if at all, per critiques in the Venn et al. paper (2006).

- Valuing having multiple authors from both community and university organizations to improve the utility, insight, accessibility, and accuracy of our project products.

- Naming that we are each a co-investigator and an actor in the work we are studying.

- Considering ethical and epistemological implications of how community leadership in Food Dignity has led us to prioritize telling important and true stories about their work, specifically, vs. an academic tendency to center "the purpose of understanding a larger class of (similar) units" (G erring, 2004, p. 342). For example, the former demands more inductive listening and analysis, including in setting the boundaries of the case; the latter encourages more narrowly focused boundaries and analysis, potentially conscribed by a priori research questions, and presumes transferability.

pantry, an advocacy campaign, a market); or on activities of an organization whose central activity is not food justice (e.g., a church). O ther studies refer to or draw from case study research with $\mathrm{CBO}$ s, but the methods and findings are not centered on that organization. 
I turn now to our case study methods and method development in Food Dignity. Also, though the methods of a larger project like ours are not entirely comparable to methods in an individual publication, I have summarized core aspects of our case study design in the last row of Table 1.

Table 1. Purposes and Case Study M ethods Used with Food System CBOs in 11 Publications

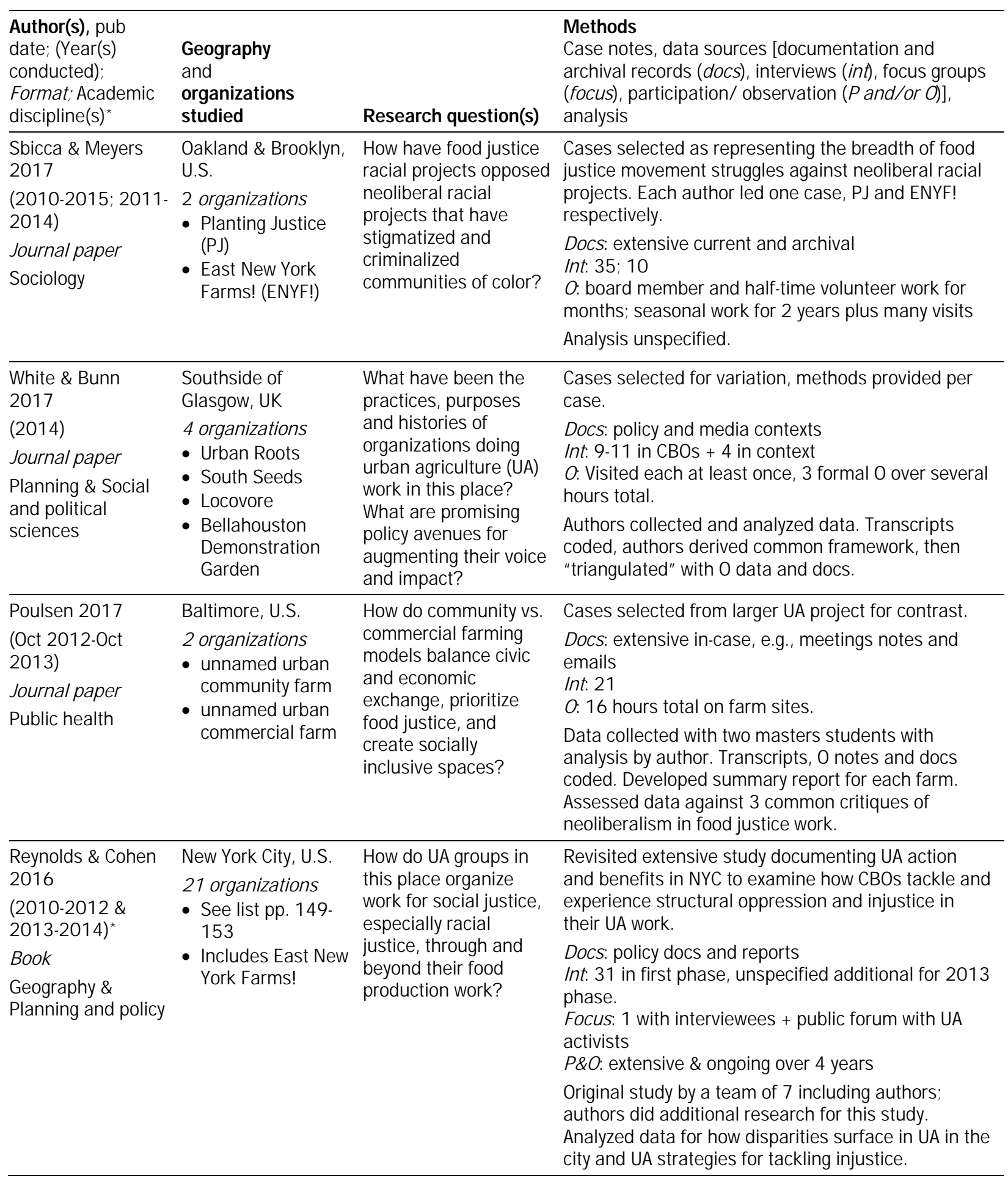


Journal of Agriculture, Food Systems, and Community D evelopment ISSN: 2152-0801 online

https:/ / www.foodsystemsjournal.org

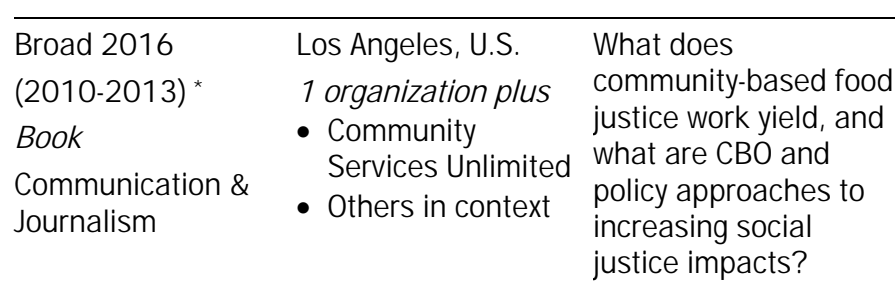

CBO chosen as "analytical entry point" to research

questions; came to questions partly through

personal involvement in food justice in LA.

Docs: 100 s of primary docs, websites

Int: $>30$

$P \& O$ : extensive $\&$ ongoing, with field notes

Author collected and analyzed data. Regularly shared and checked with stakeholders/ participants.

Analyzed data for practices and lessons on community-based social change and food justice in an age of neoliberalism with a "communication ecology" lens.

\begin{tabular}{|c|c|c|c|}
\hline $\begin{array}{l}\text { Warshawsky } 2015 \\
(2013-2014+ \\
\text { context since } \\
2006) \\
\text { Journal paper } \\
\text { Geography }\end{array}$ & $\begin{array}{l}\text { Los Angeles, U.S. } \\
1 \text { organization } \\
\text { - Food Forward }\end{array}$ & $\begin{array}{l}\text { What are challenges in } \\
\text { food waste governance } \\
\text { in this place and what } \\
\text { role do CBOs play in } \\
\text { food waste reduction? }\end{array}$ & $\begin{array}{l}\text { Reason for CBO choice unspecified, though implied } \\
\text { as it is major regional player in food recovery. } \\
\text { Docs: institutional reports } \\
\text { Int: } 7 \text { with CBO + } 43 \text { with people in context } \\
\text { O: "when possible" } \\
\text { Author collected and analyzed data. Transcripts } \\
\text { classified "by quotation content" and analyzed with } \\
\text { "triangulation." }\end{array}$ \\
\hline $\begin{array}{l}\text { Passidomo } 2014 \\
(2010-2012) \\
\text { Journal paper } \\
\text { Geography }\end{array}$ & $\begin{array}{l}\text { New Orleans, U.S. } \\
3 \text { organizations } \\
\text { - Hollygrove Market } \\
\text { \& Farm } \\
\text { - Lower Ninth Ward } \\
\text { Food Access } \\
\text { Coalition } \\
\text { - Latino Farmers' } \\
\text { Cooperative of } \\
\text { Louisiana }\end{array}$ & $\begin{array}{l}\text { How do food } \\
\text { sovereignty discourses } \\
\text { and activism impact } \\
\text { the material realities } \\
\text { and equity in low- } \\
\text { income communities } \\
\text { of color in which food } \\
\text { justice work is } \\
\text { frequently situated? }\end{array}$ & $\begin{array}{l}\text { CBOs for "vignettes" selected for variation in city } \\
\text { neighborhood of origin. Different methods described } \\
\text { for each. } \\
\text { Conversation and O with first organization. } \\
\text { O over several CBO meetings organized by second. } \\
\text { PO (volunteering) and int with third. } \\
\text { Author collected and analyzed data. Methods more } \\
\text { implicit than explicit, but analyzed data inductively } \\
\text { for themes and deductively through a "right to the } \\
\text { city" framework. }\end{array}$ \\
\hline $\begin{array}{l}\text { Ramirez } 2015 \\
(2010-2013) \\
\text { Journal paper } \\
\text { Geography }\end{array}$ & $\begin{array}{l}\text { Seattle, U.S. } \\
1 \text { organization plus } \\
\text { - Clean Greens } \\
\text { - Another with } \\
\text { pseudonym for } \\
\text { contrast }\end{array}$ & $\begin{array}{l}\text { How black food } \\
\text { geographies can enact } \\
\text { a decolonial politics } \\
\text { and provide } \\
\text { transformative spaces, } \\
\text { in contrast with white } \\
\text { ones that may limit } \\
\text { both? }\end{array}$ & $\begin{array}{l}\text { Chose two organizations in one neighborhood } \\
\text { predominately of color, one black-led and one white- } \\
\text { led, to illuminate answers to research question. } \\
\text { Docs: not specified, but results imply archival for } \\
\text { neighborhood context } \\
\text { Int: several, with leaders of each organization } \\
P \& O \text { : occasional volunteering and then active } \\
\text { participation in Clean Greens; visited other a few } \\
\text { times. }\end{array}$ \\
\hline $\begin{array}{l}\text { Sbicca } 2012 \\
(2009)^{*} \\
\text { Journal paper } \\
\text { Sociology }\end{array}$ & $\begin{array}{l}\text { Oakland, U.S. } \\
1 \text { organization } \\
\text { - People's Grocery }\end{array}$ & $\begin{array}{l}\text { How well and with } \\
\text { whom do anti- } \\
\text { oppression ideology } \\
\text { underpinnings of CBO } \\
\text { food justice work to } \\
\text { mobilize action, } \\
\text { especially by class? }\end{array}$ & $\begin{array}{l}\text { Did a case study generally because of "paucity of } \\
\text { studies" on CBOs, and with this one in particular } \\
\text { because past research on them was not useful to } \\
\text { the organization and the director was interested in } \\
\text { research with their internship program. } \\
\text { Docs: primary from CBO and any related to CBO } \\
\text { online } \\
\text { Int: } 17 \text { (7 with staff and } 10 \text { with interns.) } \\
\text { P\&O: interned for three months at } 20 \text { hours a week } \\
\text { ( 240 hours) } \\
\text { Author collected and analyzed data. Coded for } \\
\text { understandings of food justice and CBO's work for it, } \\
\text { for understanding local context; analyzed for these } \\
\text { themes and to compare intern vs. staff } \\
\text { understandings. }\end{array}$ \\
\hline
\end{tabular}




\begin{tabular}{ll}
\hline White 2011 & Detroit, U.S. \\
(2009) & 1 organization \\
Journal paper & - D-town \\
Sociology & Farm/ Detroit \\
& Black Community \\
& Food Security \\
& Network
\end{tabular}

What are lessons for
how to foster
community building
and political agency
from this CBO's work?

What are lessons for how to foster and political agency from this CBO's work?

Implied case study choice as this CBO explicitly strives for community and political agency building, explicitly chosen for author interest in Black farmers in UA.

Docs: on $\mathrm{CBO}$ history and context

Int: 10

P\&O: not mentioned explicitly, but implied e.g., attending meetings.

Author collected and analyzed data. Coded for understandings "community" and "resistance," themes of agency and responsibility, and farmer perspectives on land use in UA.

\begin{tabular}{|c|c|c|}
\hline $\begin{array}{l}\text { McCutcheon } 2011 \\
(2009-2010) \\
\text { Book chapter } \\
\text { Geography }\end{array}$ & $\begin{array}{l}\text { Calhoun Falls, S. } \\
\text { Carolina, + national, } \\
\text { U.S. } \\
2 \text { organizations } \\
\text { - Beulah Land } \\
\text { Farms of Pan } \\
\text { African Orthodox } \\
\text { Church } \\
\text { - Nation of Islam } \\
\text { food work }\end{array}$ & $\begin{array}{l}\text { How does race and/ or } \\
\text { racial identity drive } \\
\text { ideology and food and } \\
\text { health action? What } \\
\text { are their concepts of } \\
\text { community and self- } \\
\text { reliance? How does } \\
\text { this contribute to "just } \\
\text { sustainability" for the } \\
\text { organizations and for } \\
\text { blacks in the U.S. } \\
\text { generally? }\end{array}$ \\
\hline
\end{tabular}

Detailed explanation of why cases chosen, including to offer unique insights into race and alternative food movements, and almost no research done about their food work.

Docs: deep and extensive archival research with both

P\&O: worked at the Beulah Land Farms as researcher

Author collected and analyzed data using research questions as guide to provide detailed histories, motivations, strategies and actions of each and lessons.

Summary of overall Food Dignity project case study methods:

\begin{tabular}{|c|c|c|}
\hline $\begin{array}{l}\text { Porter et. al. } \\
\text { (2010-2017 + } \\
\text { Whole Community } \\
\text { Project since 2006) } \\
\text { Multiple formats } \\
\text { Community } \\
\text { partners with a } \\
\text { community- } \\
\text { centered lens; } \\
\text { academic partners } \\
\text { in nutrition, } \\
\text { education, } \\
\text { geography, } \\
\text { sociology, } \\
\text { anthropology, } \\
\text { economics, \& } \\
\text { agro/ ecology. }\end{array}$ & $\begin{array}{l}\text { Alameda County, } \\
\text { California; Wind } \\
\text { River Reservation \& } \\
\text { Laramie, Wyoming; } \\
\text { Ithaca \& Brooklyn, } \\
\text { New York; U.S. } \\
5 \text { organizations } \\
\text { - Dig Deep Farms } \\
\text { - Blue M ountain } \\
\text { Associates } \\
\text { - Feeding Laramie } \\
\text { Valley } \\
\text { - Whole Community } \\
\text { Project } \\
\text { - East New York } \\
\text { Farms! }\end{array}$ & $\begin{array}{l}\text { How do, can, and } \\
\text { should U.S. } \\
\text { communities build } \\
\text { community-led food } \\
\text { systems that generate } \\
\text { sustainable food } \\
\text { security for all? }\end{array}$ \\
\hline
\end{tabular}

Case collaborators invited for geographic and
organizational diversity, combined with practical
considerations of travel distance between academic
and community partners and of pre-existing
connections and relationships.
Docs: $>1000$ of primary docs from CBO and any
related to CBO online
Int: 150 with 121 community stakeholders and co-
investigators

$P \& O$ : extensive $\&$ ongoing by multiple insider and outsider investigators, with field notes by academic investigators, over $>5$ years

Digital storytelling: including 16 first-person videos

Collaborative pathway modelling: 5

Multiple investigators collecting and analyzing, including team coding and narrative inquiry; later a much wider array of analysis methods, either narrowed and honed to answer more specific subresearch questions or broadened to capture larger truths than such technical methods could identify.

\footnotetext{
* Academic disciplines represent the PhDs earned by the authors as listed in their curricula vitae online. Other details marked with an asterisk are not explicit in the publications cited and were provided or confirmed via personal communication with the authors.

\section{Methods Used for this Methods Paper}

The next sections of this essay include a relatively technical report on our case study methods, including my report and reflections on how and

why we came to use these methods. D ata sources include original and annual renewal project proposals to USD A; memos and emails I wrote about methods to other team members; methods sections
} 
of our codified work to date; and detailed emails and meeting notes from in-person and phone discussions among team members about our research approaches.

Then, the final section embeds the above within a larger question about how to conduct this Food D ignity case study research with about three dozen co-investigators in nine organizations fissured by and riddled with systemic inequities. Particularly prominent inequities included ones created by racism, classism, and, what I call "academic supremacy." Academic supremacy refers to systemic inequities between community-based and academic organizations (Porter \& Wechsler, 2018). I offer reflections and lessons from our experience, rather than conclusions. To inform my analysis, I consulted the data above plus additional data sources, including internal national team meeting notes and audio recordings. I also reviewed the transcripts of six interviews that three project partners and one external interviewer conducted with me between 2011 and 2016. Having spent about half my working life on this project over the last seven years, I have also consulted my memory, which I corrected, corroborated, or supplemented by re-reading these data sets and other materials, as needed, while writing this paper.

This essay represents my own experience, analysis, reflections, and learning as project director, principal investigator, and co-investigator. Several Food D ignity co-investigators have reviewed this essay for factual accuracy. In addition, Monica Hargraves provided substantial and insightful commentary on an earlier version. I am grateful for the resulting corrections and improvements. Moreover, my "reflections and learning" described here derive largely from lessons, wisdom, and questions that my teachers, mentors, friends and co-investigators offered over the past decade, especially during these last seven years of Food Dignity. I am responsible for any errors, mischaracterizations, and blindness in this work; I am also responsible for the ways in which this essay is extractive (i.e., I took knowledge, mentorship, and wisdom, digested and integrated it with my own, and now share what I learned as sole author).

\section{Food Dignity Case Study Methods and Method Development}

$D$ eciding to $\mathrm{D}$ esign $\mathrm{F}$ ood D ignity

In the 2009-10 academic year, I was finishing my Ph.D. The Whole Community Project (WCP) in Ithaca, New York was the subject of one of my dissertation case studies. The WCP project director, E. Jemila Sequeira, had been mentoring me in community organizing and anti-racism for two years. She had also become a close friend. I felt committed to securing more funds to help sustain and expand the deeply grassroots food justice work she was leading. I also wanted the world to learn from and about the extensive wisdom and knowledge of community food justice organizers, including Sequeira. The meager opportunities I could find for funding action (as opposed to research), combined with my wish to document and amplify activist expertise, moved me from claiming that I would never become an academic to applying for tenure-track professor jobs.

Then, in January 2010, I read the USD A NIFA Global Food Security call for developing "research, education, and extension sustainable programs on local and regional food systems that will increase food security in disadvantaged U.S. communities and create viability in local economies." It required that "active participation of disadvantaged communities should guide the project's assessment of best practices" and included "community organizing" as an example of extension activities (USD A, 2010). I would have felt that the call had been written specifically for me, had I not felt so daunted by its US\$5 million scale. I tried and failed to convince any senior colleagues to let me help them apply. I accepted an assistant professor position at the University of Wyoming (UW). I considered the advice I generally proffered about small grants: if you have good people with a good plan, you can secure money for it. I decided to try assembling great people and a good plan to support, learn from, and learn with food justice CBO s in the U.S.

\section{Inviting Partners}

I started with WCP. Sequeira and I had been discussing the best ways to systematically support grassroots food justice work like that of WCP for 
at least a year. I admired and wanted to learn more from her work. I had been involved in WCP since its inception in 2006 and had reams of case study data and analysis already in hand. Finally, housed within Comell Cooperative Extension in Tompkins County, WCP offered a potentially transferable institutional context. Sequeira and her supervisor immediately agreed to collaborate.

In choosing which CBOs to invite as partners in addition to WCP from a research perspective, I wanted to maximize variation in the organizations and their contexts. From a feasibility perspective, I considered constraints of travel, including proximity between community-based and universitybased partners to enable frequent documentation, participation, observation, and collaboration. (At the time, I did not even consider the possibility of having a CBO partner that was more than a few hours drive from an academic partner.) Also, I needed to assemble the team quickly to finalize a proposal before the June application deadline, and each CBO needed to have an umbrella organization with 501(c)(3) status so that the organization could accept and manage a subaward.

I asked leaders of East N ew York Farms! (ENYF) in Brooklyn, New Y ork. ENYF was founded in 1998 and housed in a community center (United Community Centers) in a diverse and dense urban setting. WCP had once co-hosted a food justice event in Ithaca, New York with them. A non-incorporated local foods organization in Laramie pointed me to a person organizing food-sharing activities in what later became Feeding Laramie Valley (FLV) of Laramie, Wyoming, which is housed within a very experienced not-for-profit social change organization called Action Resources International. Dig D eep Farms (D DF), located in the Bay area of California, was founded at about the same time I was organizing the proposal. Under the auspices of a police activities league (D eputy Sheriff's Activities League), D D F was founded by an officer in the Alameda County Sherriff's D epartment. I only

\footnotetext{
3 In 2013, the C-PREP/ Food Dignity relationship changed. Gayle Woodsum, founder of FLV and executive director of Actions Resources International, became the communityuniversity liaison and re-shaped that role. In 2014, the C-
}

heard of it because the person who had agreed to be a liaison between universities and communities in the project had later agreed to become DD F's general manager with the other half of his time. I thought having a CBO associated with local government would add institutional diversity, and having someone who was "inside" one of the CBO s as part of the project-wide team would bring at least as many advantages as disadvantages. I also wanted to include a tribal-led CBO with ties to Wind River Indian Reservation (the only reservation in Wyoming). I believed that such an organization would offer different, possibly paradigmatically different, expertise and experience about food insecurity and sustainability compared to the other four partnering CBOs. After several months of my increasingly desperate search for such a partner, a Wyoming cooperative extension agent put me in touch with Blue Mountain Associates (BMA). For reasons the leaders of these organizations outline elsewhere in this issue, they each accepted my invitation to participate in Food Dignity and began contributing to the project design (D aftarySteel, 2018; Neideffer, 2018; Sequeira, 2018; Sutter, 2018; Woodsum, 2018).

I also assembled a project-wide team including people from UW, Comell University, Ithaca College, and from a "think-and-do" tank called Center for Popular Education, Research, and Policy (C-PREP; which is led by the person who also connected me with D DF). On that front, I began by inviting collaborators whom I knew and trusted and who had relevant academic expertise. However, at UW, I simply cold-contacted people who appeared to have relevant expertise. I did not yet know anyone there (we developed the proposal while I was still a Ph.D. candidate living in Ithaca, New Y ork), but I thought reviewers would find an application without collaborators at my own institution implausible. Several people from each organization - community and academic - became project co-investigators. ${ }^{3}$

PREP/ Food Dignity relationship ended. A research staff member who had been working under the auspices of $\mathrm{C}$ PREP, Katie Bradley, was also a graduate student at University of California, Davis (UC Davis). To retain her as part of the 
Summary E lements of 0 ur Research D esign Described according to the five components of case study design outlined by Y in (2009, p. 27), the key elements of the Food Dignity case study research design with the five partnering $\mathrm{CBO}$ s are:

- The study's research questions: How do, can, and should U.S. communities build community-led food systems that generate sustainable food security for all? More specifically, we examined how each of five $\mathrm{CBO}$ s catalyzes and supports that goal and, more provisionally, the outcomes of and lessons from its work.

- Study propositions: As we wrote in our proposal to USDA, we took the ethical stance that human and community agency in food systems is an end in itself, while hypothesizing that building civic and institutional capacity to engage in sustainable community food systems for food security action would improve the sustainability and equity of local food systems and economies.

- Unit of analysis: The five CBO s are our organizational unit of analysis. This "unit" includes as much current and historical context as each CBO s deems important for understanding their organization's work. The CBO leaders were better placed to know where to draw those boundaries than outsiders (see also Bartlett \& Vavrus, 2017). Within the $\mathrm{CBO}$ s, we have also conducted some nested studies more narrowly documenting a sub-set of their work (e.g., a farmers market).

- L ogic linking data to propositions and criteria for interpreting the findings: These components are described in the sections that follow. Key elements of this logic and criteria included: i. A "hyper" triangulation of data and analysis via multiple investigators collecting and analyzing multiple forms of data using multiple methods over at least five years.

team, I created a new subaward with UC D avis that supported her in finishing her PhD studies and then as a postdoctoral ii. D evelopment of a collaborative pathway model with each $\mathrm{CBO}$, linking activities with actual or anticipated outcomes.

iii. Examination of how each $\mathrm{CBO}$ invested and leveraged a US\$67,800-ayear "community organizing support package" as a partial indicator of what food system change strategies they found most successful, promising, and/ or important.

iv. Regularly checking analysis and interpretations with multiple communitybased and university-based coinvestigators and stakeholders.

$D$ ata Sourœes

We gathered multiple forms of case study data with, from, and about each CBO between 2010 and 2017. The four main types of CBO case study data we have collected over seven years are:

1. D ocumentation and archival records. We collected and read thousands of files, later filtered (per analysis section below) to 100200 key documents per CBO for more detailed analysis. These included:

a. CBO-provided files dating from before our collaboration began (e.g., grant applications, memos, fliers, reports, etc.).

b. Public documentation and records such as news media, videos, and any previous research with the $\mathrm{CBO}$ s. Academic partners searched for these retrospectively and concurrently.

c. CBO-based and project-wide teams gathering additional data files during the project.

2. Interviews (150 total, transcribed and analyzed):

a. Of project co-investigators and other stakeholders playing central roles at partnering $\mathrm{CBO}$ s $(\mathrm{n}=71)$, conducted by co-investigators, often multiple times ( $\mathrm{n}=100$ total interviews).

scholar. Technically, UC D avis became our fourth academic partner at that time. 
b. Of additional CBO stakeholders (e.g., minigrantees, gardeners, market vendors, interns) $(n=50)$.

3. Participation and observations over five years:

a. Ongoing, by full-time "insiders" who are CBO employees and Food Dignity coinvestigators, recorded mainly via interviews, discussions with academic partners, meeting notes, and in annual reports; sometimes in private journals and/ or field notes.

b. In frequent visits to CBO s by local academic "outsiders" (graduate students, research staff, and/ or faculty) who reside nearby, usually recorded in field notes.

c. During visits to $\mathrm{CBO}$ s by projectwide team members who did not live locally and during informal communityacademic meetings when co-presenting at conferences, recorded in field notes. For example, I made 31 total visits to the four CBO s (excluding FLV, which is located where I live and work) over five years.

d. D ocumentation of our 7 national team meetings in detailed process notes made by project staff and graduate students.

4. Products by co-investigators:

a. Food Dignity Collaborative Pathway Models ( $n=5$, one with each CBO) (Hargraves et al., 2017).

b. Digital stories, including 16 first-person ones (Food D ignity, 2015).

c. Community minigrant programs developed by each CBO ( $\mathrm{n}=4$, US $\$ 30,000$ awarded in each; D DF did not develop a minigrant program) and brief reports on each individual project funded $(\mathrm{n}=92)$ (Hargraves, 2018a).

d. Our presentations.

e. Our publications.

f. Annual reports by $\mathrm{CBO}$ and academic partners to me and reports by me to the funders.

These data forms were part of the original planned research design, with the exception of digital stories and the collaborative pathways models as explained below.

D igital stories

The digital stories originated with a suggestion by Sarita D aftary-Steel, the program director of ENYF, during the proposal design phase. She suggested adding Photovoice based on a previous good experience ENYF had using that participatory method. After brief discussions, we added this method to the scope and budget of each CBO and to the overall project outlined in the proposal. We included a formal training in Photovoice methods as part of our first team meeting in May 2011. During and after that training, several co-investigators who were also experienced community organizers said they had been using similar, semistructured methods of photo narrative in their pursuit of social change for decades before academics codified it as a research method (Wang \& Burris, 1997). We agreed to broaden the approach options beyond the formal Photovoice methods to include other means of photo and video narrative and storytelling.

By 2013, each CBO had adapted Photovoice methods or designed their own processes for creating a set of narrated photos to publicly share information about food justice, injustice, and systems work in their communities with community stakeholder groups of their choice (see http:/ / www.fooddignity.org). CBO leaders have also produced multiple video stories about their work. For our sixth national team meeting in January 2015, co-investigators decided to commission a three-day digital storytelling workshop. This yielded 16 first-person digital stories and a minidocumentary (Food D ignity, 2015), plus several other video products. These first-person videos are key data sources for some papers in this issue (see, e.g., G aechter \& Porter, 2018; Porter, 2018a). More importantly, they are profound, published products in their own right.

Collaborative pathway models

The Cornell co-investigator who led the minigrant program evaluations with the CBO s in Food Dignity, Hargraves, also brought expertise in pathway modeling. That modeling method provides an 
inductive means of producing visual theory-ofchange models by linking program activities to (desired and actual) short, medium, and long-term outcomes with directional arrows. When Hargraves joined the project team in June 2011, she told me and several others about pathway modeling (Urban \& Trochim, 2009), suggesting it might serve our project goals.

At first glance, the complexity and time demands of that modeling process, coupled with the spaghetti-looking mess of the resulting models, made me skeptical about the approach for our project. After our first Food Dignity team meeting in May 2011, tensions were already high between my demands for a high quality and quantity of data from $\mathrm{CBO}$ co-investigators vs. their priorities relating to community action. As I came to understand later, the insufficiency of the CBO subaward funding to cover direct and opportunity costs of investing in research tasks that did not immediately support their priority actions exacerbated this tension (see the discussion here and also Porter \& Wechsler, 2018, this issue). But even then, I could not imagine proposing that $\mathrm{CBO}$ s do even more.

However, in 2014, Sequeira, the WCP director, was seeking ways to document and illustrate the complexity and outcomes of her food justice work. Pathway modeling seemed worth trying. As described elsewhere, ultimately each CBO helped to reshape the modeling approach to rest on a values foundation, and then seized on ways such co-developed models could serve their organizations. With an additional collaborator recruited to help with this major addition to our methods, Hargraves worked with co-investigators and other stakeholders at each CBO to develop a model (Hargraves \& D enning, 2018).

The resulting set of five Food Dignity Collaborative Pathway Models articulate the activities, expertise, goals, and strategies of each of the five CBO s (Hargraves et al., 2017). If a case study with each CBO was analogous to a person's body, I have come to think of the models as illustrating the combined skeletal, circulatory, nervous, and muscular systems of each organization--including the (even) more metaphorical hearts and brains of the organizations and their work. They each stand on their own as a rich and rigorous form of non- narrative case study. The models also provide rich data sources for further analysis.

$\mathrm{D}$ ata $\mathrm{A}$ nalysis and $\mathrm{D}$ iscussion

Here, I take an auto-ethnographic approach to describing and discussing how we analyzed our data, how we changed our analysis approaches, and why.

A sk ing three questions: D o, would, and should O ur leading research question-- how do, can, and should U.S. communities build community-led food systems that generate sustainable food security for all?--is really made up of three questions.

Given the dearth of research on these questions with food justice CBO s back in 2010, when we proposed this project, the do question's descriptive focus was the primary one we proposed to answer. It was also the one we hoped to answer most completely, using all the case study methods outlined here with the five $\mathrm{CBO}$ s partnering in Food Dignity. In particular, the collaborative pathway models outline every core activity each CBO does and why. We are analyzing the rest of our data to illustrate and demonstrate how, and how much, the $\mathrm{CBO}$ s engage in these activities.

We have reframed the can question more narrowly as a would question: if CBO s had more resources, how would they spend it? In other words, we agreed that highlighting how the five $\mathrm{CBO}$ s spend their time and the additional resources provided by the Food Dignity subawards would help illuminate their priorities, needs, and strengths by representing their best bets for achieving their goals based on their expertise and experience. Therefore, our primary data for answering this question came from analyzing the annual narrative and financial reports written by each CBO describing how and why they invested their Food Dignity funding. O ther key case study data informing our answers to that question are the long-term outcomes in the pathway models, minigrant program designs and awards, grant applications for other funding, interviews with CBO leaders, and any products (beyond the annual reports) authored by $\mathrm{CBO}$ co-investigators.

We founded the project on the ethical meaning 
of should: in a democratic society, we have an ethical imperative to invest in civic capacity and control, including in building sustainable community food systems for food security. Empirically, we aimed to document and provisionally assess diverse ways in which CBO s can make such investments (e.g., minigrants for action, support for professional development travel, mentorship). We also sought to determine how much these investments contribute to community food systems and the local leadership within them. For documenting these actions, with process and early outcomes, we combined case study methods with other research methods. The other methods have included quantifying garden harvests (Conk \& Porter, 2016), conducting a small randomized controlled trial on the impact of minigrants (Porter, McCrackin, \& Naschold, 2016), and assessing cover crop contributions to urban garden soil fertility (G regory, Leslie, \& D rinkwater, 2016).

In all three questions, we aim to characterize and partially assess the CBO s' work within the context of the activities and goals they specified in their collaborative pathway models. In other words, we are anchoring our primary analysis within this internal frame of the CBO s' goals. However, in secondary analyses across cases, we are also imposing external lenses to help characterize the collective contributions of CBOs to the national food justice, food security, and food system movements. For example, this might include asking the research questions posed by the studies in Table 1 of our own data set. These kinds of analyses appear in included papers discussed in the "asking more specific questions" section below.

\section{Shifting modes of listening}

As principal investigator, seeking epistemological as well as ethical rigor, I wanted to find ways to systematically listen to our data and to the expertise

\footnotetext{
4 These categories (with a few examples of subcodes within each) were: money (e.g., cash flow, grant administration, sales), action (e.g., bees, labor conditions, donate food, garden, raise public awareness), context (e.g., individual, national, CBO project), definitions (e.g., community, dignity, sustainability), Food D ignity support package themes (e.g., minigrants, community and academic relations, research), overarching/ big
}

of community-based co-investigators. I had proposed semi-open coding across documents from all five $\mathrm{CBO}$ s as one of the key research methods. For the first three years of the project, I led a small team of four part-time research staff members to develop a large, relatively generic coding vocabulary of 102 codes in seven categories. ${ }^{4}$ We then apply it to analyze the textual data collected. For example, an array of codes under the category of "action" were designed to help us map what each CBO was doing within different parts of the food system (i.e., to what extent did they focus on producing food, teaching people production skills, labor issues, etc.). We also developed a file naming system where a prefix identified the date, partner (e.g., UW, D DF, ENYF), any sub-project focus (e.g., minigrant or a CBO -specific program), and file content type (e.g., flier, email, grant application, field notes).

I assigned a team member to organize and code each CBO's files. I also read all the data files, examined reports from each CBO's "hermeneutic unit" (we used Atlas.ti, which uses that phrase to identify each set of coded files), and spotduplicated some coding to check for overall consistency in our use of the codes. At first, we coded nearly all incoming and historical files. Later, though we always read, categorized, and saved every file, we began filtering to code only those that added new information. For example, if a CBO provided several files about one workshop, we would code just one or two with the most data in them (e.g., notes from the workshop and a handout provided, but not flyers and email announcements).

Organizing and coding the files made coinvestigators from outside the $\mathrm{CBO}$ s read them closely. This enabled academic co-investigators to learn key elements of the history, context, and actions of each organization. However, by 2013, insights from insider and outsider time spent

picture (e.g., success, challenge, disagreement), strategies in use (e.g., framing, networking/ partnering, ceremony/ celebrate, start where people are), and themes (e.g., poverty, values, crime/ violence including prevention, oppression). These exclude dozens more CBO-specific codes (e.g., identifying Whole Community Project's work on G ardens for Humanity or Dig D eep Farms' work on Furthering Youth Inspiration). 
together (i.e., participation and observation), internal annual reports, and a more holistic analysis of interviews and field notes (i.e., narrative inquiry; see for example Clandinin \& Connelly, 2000) meant that this generic coding was no longer adding to our understanding or information about the CBO s' work. In addition, community-based investigators were increasingly sharing sensitive data that were not suitable for sharing with all members of the coding team (e.g., confidential personnel information and talk about other Food Dignity collaborators). Also, much of this "data" was increasingly conveying complex forms of analysis, interpretation, and insight, unsuitable for the depersonalized and decontextualized slicing and dicing that coding entails. By mid-2013 we were no longer coding generically in this central way. We needed new approaches to analyzing our data.

Actually, we had needed new approaches to analyzing our data from the start of this project. As mentioned above, I led a small team in developing a shared coding approach. This was within our first six months. In November 2011, at our second allteam meeting, I presented the approach to the Food D ignity team. I was simultaneously trying to explain technically what coding is, while soliciting feedback about how to improve our approach. When I listen now to the audio of that meeting, I deem my approach to be a triple fumble. O ne, it was a little late to be asking for substantial participation and collaboration, for the first time, on an already-piloted design. Two, I explained even the technical basics concerning the purpose of coding so poorly, that today even I can hardly follow what I was trying to say. Three, I initially failed to respond to some profound and insightful questions and concerns, both scientific and ethical; I simply repeated technical details and vague reassurances that the CBO s would be able to review and cointerpret reports from the academic team's coding. As the project PI, I held systemic privileges and powers that meant I generally kept getting the ball back, even after a series of fumbles such as those.

\footnotetext{
${ }^{5}$ I was neither the first nor last person on the team to struggle with challenges of this sort and scale. I mention my own situation here because it so heavily impacted how I
}

When I listen to the 2011 audio of that conversation, I hear both community and academic-based leaders striving to shape a shared path towards a shared goal, while also generously encouraging, enabling, and allowing me, personally, to try again.

Near the end of that coding discussion, we agreed that we needed to find a way to do this kind of analysis together, in ways that serve common food justice goals while also fulfilling commitments we made in the project proposal. Then I said, "There aren't a whole lot of models for that." People laughed. I added:

Especially something as complex as this, even as straight up academic research, even if we did it conventionally, it would be hard. But that's not what I set out to do. That's not what you came here to do. That is not what we set out to do. That is not what we're going to do. And that story, the story that is unfolding here, I think will be the most important thing out of this [project].

However, I kept charging forward with only minor modifications to that coding approach for at least two more years before finally stopping, mostly because it was not proving to be epistemologically useful as a way to listen (which, for the record, was one of the concerns raised by community coinvestigators that November, and later raised by the other members of the coding team).

I was afraid to stop because I still did not know what our new way should be. Normally, I would not have tolerated such uncertainty for long. However, in D ecember 2012, I had also become a stage-3 breast cancer patient. The physical, emotional, and temporal drains of an eight-month treatment regime suddenly made me feel patient about, or at least resigned to, this methodological uncertainty. My exhaustion, plus more important things to be afraid of than not coding Food Dignity textual data, rendered me an increasingly participatory PI. ${ }^{5}$

participated in and led the project thereafter. (I would like to note that I have no reasons to believe, at the time of this writing, that I am anything but healthy.) 
Telling a different story

From the start of the project, I had described to the team of Food Dignity co-investigators my image of a series of five, $10-15$ page case stories about the work of each food justice CBO. They would all follow a similar format, containing similar sections, and would be useful both for our research project and to the CBO s. I recall people nodding politely.

When I began talking seriously about implementing this plan, G ayle Woodsum (FLV founder and Food Dignity community-university liaison) noted that my case outlines would not result in stories. My plans would reduce forests of meaning about what each CBO does and why to tree stands of facts. I conceded, recasting "that nuts and bolts information as being an appendix to the case studies." She was still worried that some people might confuse those "nuts and bolts" with the real stories, noting, "I've spent years trying to get a different story, so I don't want this [nuts and bolts] to be seen as the core of the case studies." But we agreed I could try attaching my "appendices" to the real case stories, which would be produced primarily by community-based coinvestigators.

Then, under my guidance, one of the research staff collaborators followed my outline to draft one of these "appendix base cases" about D D F's work. On perhaps our fifth redraft, and in the face of near silence from community-based co-investigators at D DF about our drafts (who have always given feedback before and since), she finally proclaimed the product as "heartless." I finally admitted that my proposed approach was more like busywork rather than being the rigorous, evidencebased and useful foundation for the rest of our work that I had envisioned. I finally realized that the collaborative pathway models that Hargraves \& D enning were developing with stakeholders and co-investigators at each CBO filled that role, and more, in our case study work. In addition to being a rigorously and systematically produced form of structured and explicit knowledge (i.e., research), the models also surface expertise that communitybased co-investigators developed over decades of community organizing experience.
Sharing voices, but not risk

Academic voices frequently drown out the stories of people who are doing the work being studied and obscure the expertise that guides them, including in Food Dignity. For example, the coding vocabularies and my case outlines were pressing academic frameworks onto the $\mathrm{CBO} \mathrm{s}^{\prime}$ data and expertise. Though such externally imposed approaches can help answer some narrow research questions and helped me to grasp basic facts and truths of each case, they were excluding and obscuring too much insight to enable rigorous and useful storytelling about the CBO s' work. I had been asking myself and co-investigators how we should shift our listening; the answer was largely entwined with who should be doing the talking.

D oing research is usually part of an academic's job description. For example, even though the Food Dignity grant has ended, I still am paid to do research for $65 \%$ of my time, nine months out of each year. I was paid and, in other ways, rewarded for the time I invested in writing this paper. This is one reason that academic voices are prominent in Food Dignity, especially mine, such as in this paper and the case study research process it describes.

This kind of time, space, and support for research is, comparatively speaking, almost nonexistent for community co-investigators in Food Dignity. Harking back to that November 2011 team meeting, I kept mentioning the research budget each CBO had as part of their subawards, saying, for example, "Of course you have your own research questions, and have a research budget to do whatever makes sense for you. To support your labor in providing files to us, or to hire researchers or yourselves to document and tell your story." I was referring to research budgets I had proposed and then allocated to each CBO partner; these averaged US $\$ 12,900$ per organization each year for staff time to assist the lead community organizers (Porter \& Wechsler, 2018). Unlike academic partners, no CBO staff joined the project with preexisting job descriptions or goals that included doing the kinds of research I was asking for.

In my view, much of our most useful, richest, newest and truest knowledge generation and dissemination in this project has come from work in which community-based researchers served as 
lead or sole authors. The digital stories and collaborative pathway models are the prime examples of this. The digital stories indicate the importance of making direct investments in offering time, space, and technical support for knowledge codification in production. Academic partners receive this kind of support and time in spades, usually as a core function of their paid jobs. Creating this option for community partners requires intentionality, funding, interest, and attention to opportunity costs. In this vein, we also organized a small writing retreat in September 2015 for interested partners. Their work forms case stories that we are releasing in phases on a renewed project website, and might also share in book form. In addition, the collaborative pathway modeling illustrates the value of sharing community expertise. It also illustrates how academic partners can sometimes help supply and apply frameworks and methods to assist with that, without being overly reductive.

Yet, for CBO leaders, the opportunity costs of doing research are extremely high. Funding is necessary to help bridge this, especially in small organizations. With ENYF, we once had the chance to partly resolve this issue when D aftarySteel stepped down as the program's director, was in between jobs, and was interested in leading the ENY F case study research. Using a dynamic presentation software (Prezi), and archive and file assistance from an academic partner, she developed and narrated a tour of the drivers, actions, and meanings of ENYF's first 12 years of work (D aftary-Steel \& G ervais, 2015). In response to interest from other partner $\mathrm{CBO}$ s, she developed a market guide (D aftary-Steel, 2014) and, later, a youth program guide (D aftary-Steel, 2015). D rawing on her expertise regarding unattainable demands some funders made of ENYF, she led a collaboration with someone at D DF and an academic partner to document it (D aftary-Steel, Herrera, \& Porter, 2016). She developed those ideas and the fuller story of ENYF into a book chapter, in partnership with people still at ENYF and academic partners (D aftary-Steel, Porter, Gervais, Marshall, \& Vigil, 2017). Most recently, she co-produced a video about the variety of forms of urban agriculture, contrasting the communitycentered origins and activities of ENYF with high- tech, sometimes profit-centered urban food production projects (D aftary-Steel \& Noguera, 2017). With the chance to develop research products while no longer simultaneously directing a CBO, she was highly prolific.

However, community organizers leaving their CBOs to do full-time research is hardly a desirable or scalable solution to the issue of how to share their voices. Paid sabbaticals and part-time endowed chair positions might be a viable solution. Grant awards or subawards that support $\mathrm{CBO}$ s in hiring research staff, on salary, not just stipends, might be another.

Finally, even if direct and opportunity costs are covered, CBO s still face another layer of risk in participating in, or being the subject of, research: results might be used in ways that harm the goals and interests of their organization and community. Harking back again to our November 2011 team meeting, one community leader spoke explicitly about how our results might shape USD A funding policy for decades to come, for better or possibly for worse. Over the years of our collaboration, coinvestigators based at four of the five partnering $\mathrm{CBO}$ s independently and explicitly told me that even if I do not use the knowledge they share in ways that would harm their work, others might once we disseminate it.

That said, the risks of harm are even greater, probably, within a collaboration. In a September 2011 interview, after I had listed several of my fears about leading the project, the academic coinvestigator interviewing me asked, "what do you think is the worst thing you could do?" I answered, to "make any one or all of the community partners feel betrayed, to betray their trust." I paused, adding, while laughing at myself, "to the extent to which I have their trust." I then admitted, "I probably already have [betrayed] in small ways," telling a story about how I had set up interviews with people in the Ithaca food movement without having consulted with Sequeira, the WCP community organizer. My striving to be a trustworthy academic partner does not mean I am entirely so. My academic, race, and class privileges offer me hundreds of blind spots, which are always difficult- 
and never convenient 6 - for me to identify and remove.

During this project, I was awarded an endowed chair position and then tenure and a promotion. I sit in that chair now, or enjoy the standing desk option UW has provided, lauding the wisdom and expertise of the community co-investigators. O ne of the five CBO s was dissolved at the end of the Food Dignity funding - WCP. Sequeira is one of several community co-investigators who have since lost their jobs. O ur collaboration did not cause this, but certainly did not prevent it either.

In sum, I asked community-based activists to collaborate on research in Food Dignity because I knew their insight, experience, expertise, and leadership were essential to generating new, relevant knowledge about building food-secure, sustainable and equitable communities. Even if I had adequately budgeted to cover direct and opportunity costs, and even if I had stepped back enough to "share voices" as much as I had claimed I meant to, the CBO s would still have been taking all of these risks above, whereas academics like myself stand mostly to benefit. ${ }^{7}$

\section{A sking more specific questions}

Starting in 2015, small teams or individual coinvestigators began asking more specific research questions of our growing catalog of case study data. With those narrower questions in mind, investigators returned to coding textual data. This time, they focused on relevant data subsets and developing coding approaches specific to their research questions. For example, for a paper in this issue (Porter, 2018a), I searched our interviews, documents, digital story video transcripts, and collaborative pathway models for every instance

\footnotetext{
6 I intend the superficiality of this word, "convenient," to convey how insidiously daily the maintenance of systemic oppression is, and my own blithe complicity and contribution to it.

7 I have often heard academics describe risks of engaging in participatory research (as opposed to, for example, research that excludes the communities involved or that is not about community-level issues). Sharing power, via collaboration, does reduce academic control, which can feel risky (though also, as I have briefly begun to outline in this paper, it also improves relevance and rigor, which increases quality).
}

and variation of food-production-related words to characterize the production related activities and goals of the five $\mathrm{CBO}$ s. A graduate student examined a subset of our data for social movement framing used by Food Dignity co-investigators (G aechter \& Porter, 2018). Another paper assesses case study data along with several other data forms to outline outcomes of gardening (Porter, 2018b).

As an academic, I am interested in these questions as well as questions that have been asked in previous studies, such as those listed in Table 1. I do not feel, however, that I could make a convincing argument to community co-investigators in Food Dignity describing how these are substantively more than academic questions. Even if we do manage to ask and help answer some of these most pressing questions, knowledge gaps arguably make up only a small part of the chasm between society today and a society with food justice.

V erifying credibility and rigor "Triangulation" is an oft-cited approach for checking and verifying research analysis and results, especially in qualitative research. Methods theorists describe four kinds of triangulation (D enzin, 1978; Patton, 2002, p. 247). Each kind is listed below, along with the ways in which we employed triangulation in the Food Dignity case study research:

- D ata triangulation, i.e., using a variety of data sources. We have gathered and are analyzing myriad forms and quantities of data sources, as outlined above.

- Investigator triangulation, i.e., several researchers analyzing the data. In the parable of blind men feeling an elephant,

\footnotetext{
However, for example, no matter what happened in Food Dignity, the graduate students could still earn their degrees and my tenure track job that started in 2010 offered me seven more years of job security than any of the CBO positions had except for the sheriff at D DF. An academic can even do a case study about a CBO that dissolves or lets most staff go for lack of funding. The risks for academics were so minor compared to those for community-based partners, in this project and in life generally, that I prefer not to use the same word (risk) to describe them both.
} 
the Food Dignity team has the elephant surrounded with three dozen or so coinvestigators. Also, individual coinvestigators always check their data and interpretations with relevant individuals and CBO leaders (member checking).

- Theory triangulation, i.e., viewing the data through various theoretical lenses. Here, I venture two related claims. O ne, Food Dignity is more a- and post-disciplinary than trans-disciplinary. The leadership from community-based co-investigators has led us to center our analysis around communities and people, as opposed to, for example, food or soil. Two, the lens variation among co-investigators has often been paradigmatic, in the Kuhnian sense of differing worldviews (Kuhn, 1962; Porter, Herrera, Marshall, \& Woodsum, 2014). This is in addition to the array of disciplinespecific theory and methods the academic co-investigators (whose disciplines are listed in the last row of Table 1) have brought to our case study and other research.

- M ethodological triangulation. i.e., using a variety of methods in a study. The academic case study methods we have used include semistructured coding of textual files, narrative inquiry with some interviews (Riessman, 1993; Riley \& Hawe, 2005), collaborative pathway modelling (Hargraves \& D enning, 2018), and institutional ethnography (Campbell \& G regor, 2004; D. E. Smith, 2005). Among academic-based investigators, we used auto-ethnography with technical approaches approximating Anderson's (2006), but always with ethical commitments mirroring Denzin's (2006). For examples from Food Dignity's work, see the graduate student reflective essay in this issue on emotional rigor (Bradley, G regory, Armstrong, Arthur, \& Porter, 2018), and (Porter et al., 2014; Wechsler, 2017).

In his Research is $\mathrm{C}$ eremony guide to indigenous research methods, Wilson (2008) cites a friend who questions the idea of triangulation: "We came up with 'encircle'... And rather than it being valid or reliable, I thought that maybe it's authentic or credible, and rather than focus on being reliable, it's relational. How it relates. So that's the test" (p.101). Striving for ethical and emotional rigor, in addition to epistemological, is a promising step towards this kind of relational credibility (Bradley et al., 2018).

\section{Reflection and Conclusion}

Food insecurity, racism, and other forms of social oppression, frayed community ties, food system unsustainability, and gross economic inequity are wicked and systemic social problems in the U.S. They are literally life and death problems, killing people with proximate causes such as gunshots, addictions, cancers, and complications of type II diabetes. In this context, the most relevant use of the word rigor is with mortis, not about research methods. Resolving these problems drives the work of food justice CBOs, and they do it by building on the expertise, relationships, and other assets in their communities (see, for example, nearly every other paper in this issue).

In spite of these costs and risks, the $\mathrm{CBO}$ leaders let the academic co-investigators learn with and from their work, and often actively taught and mentored academic partners. As with the Community and Regional Food Systems project (Ventura \& Bailey, 2017, p. 3), these leaders were clear that they did not want to be studied, neither as individuals nor as organizations. In spite of all the risks, and the insufficient subaward funding, they were generously willing to share some of what they learned through decades of community organizing and food justice work and were willing to study, as co-investigators, in a cycle of funded action and reflection.

My experience as PI of Food Dignity leads me to hypothesize that the only chance of research contributing to $\mathrm{CBO}$ s resolving these problems is striving for ever-more-equitable communityuniversity action research partnerships and everstronger relationships among collaborators ["bridge the distance between our cosmos and us" (Wilson, 2008, p. 137)]. I think this for at least two reasons. One is that community-based food justice activists will push academics to make resolving these problems the focus of their teaching, action, 
and research. They certainly did in Food Dignity. The other reason is that people doing the work have knowledge, expertise, and relationships that are essential and irreplaceable for doing useful and rigorous action research about community food justice (or about any other community-based issue).

However, our community-university relationships in Food Dignity were never equitable. Following the guidance of our Food D ignity Values statement (Hargraves, 2018b), we did strive for ever greater equity. Six strategies we used for traveling that path together in a good way (Porter, 2016) included the following, with summaries of their impacts in italics:

1. Issuing subawards to each $\mathrm{CBO}$ and mostly paying these in advance, rather than arrears (Porter \& Wechsler, 2018). This enabled the partnerships to form in the first place. Few of the CBO s could have afforded to be paid in arrears for the expenses incurred.

2. Investing financially and temporally in coauthorship with and first-person work by community-based co-investigators. Academics are otherwise the only ones who would be paid to do this work.

3. Investing heavily in spending in-person time together during seven national all-team meetings, plus smaller group working and socializing at a writing workshop, dozens of co-presentations at national conferences, and during site visits. This created and enacted our relationships and research collaborations.

4. Supporting a community-university liaison as a half-time position, who also worked as a co-investigator based at one of the five CBO s partnering in the project. Gayle Woodsum, also of FLV, took on this role in 2013. This was a first step in slightly reducing inequity between academic and community partners, including via having a CBO advocate and supporting community research more extensively. Woodsum also introduced the next two strategies.

5. Engaging an external facilitator for two of our national team meetings, Ms. Lila Cabbil.
Cabbil and Mr. Malik Yakini had previously facilitated anti-racism trainings at our meetings. I would not ever again host such meetings without a strong, external, community-centered and anti-racist facilitator to help reduce the communityacademic and other power inequities during negotiations and discussions.

6. O rganizing a pre-team-meeting communitypartner-only retreat without academics in 2013, facilitated by Woodsum and Cabbil. People with less negotiating power at any given table benefit from having in-group time to deepen personal relationships and establish shared group priorities and strategies to help increase their power (see, for example, Cervero \& Wilson, 2006).

Including for reasons described above, I believe these helped improve the equity of our partnership and depths of our inter-personal relationships which also, in turn, I think enriched the quality, quantity, and the epistemological and ethical rigor of our research. These two kinds of rigor are the first two " $\mathrm{e}$ " $\mathrm{s}$ of triple-e rigorous storytelling.

The seventh key to our collaboration on this case study research was the gift of substantial time and money--ultimately seven years and nearly US\$5 million. We needed this time not only to complete an enormous scope of work, but to learn to do it together. In the cliché-but-insightful framework for describing stages of group collaboration (Tuckman, 1965), we formed and then stormed--frequently and at times heavily--particularly through our second year. In our 2014 national meeting, a small working group developed what became our Food D ignity values statement, marking a turning point towards our most collaborative and productive time from then until the end of our funded time together in 2016. We also were given the national Community-Campus Partnerships for Health award in 2014, a recognition of action-research collaborations striving for equity within their partnerships and in public health outcomes.

An eighth factor has been my excruciating, transformative, and love-infused labors to learn 
how to lead and how to follow with personal and academic humility, and the similar work of other academics who have attempted this path with me. This is a journey that I will explore in future writing, and one in which the CBO co-investigators were my guides, mentors, and teachers. (To avoid sounding too romantic about this, I will add that I often verbally characterize some of this guidance as "schooling me" and "slapping me upside the head." We shared lots of love, but little romance.) This depth of engaged emotion is the third " $e$ " of the triple rigor in rigorous storytelling. As Wilson (2008) cites a friend saying, "If research doesn't change you as a person, then you aren't doing it right" (p. 83).
The ninth, and turnkey, factor is the generosity, courage, and ferocious dedication to justice of the community-based coinvestigators in Food Dignity. They were doing the work before this project, and continue to afterwards. At risk of delaying or even derailing their journeys towards food justice, they tolerated or even embraced academic outsiders in following them down some of this road-- the one they are making by walking.

\section{Acknowledgments}

I am grateful to collaborators, friends, and mentors in Food Dignity. Thanks especially to Monica Hargraves, E. Jemila Sequeira, Katie Bradley, and Gayle M. Woodsum.

\section{References}

Alkon, A. H. (2007). G rowing resistance: Food, culture and the Mo' Better Foods Farmers' Market. G astronomica, 7(3), 93-99. https:// doi.org/ 10.1525/ gfc.2007.7.3.93

Alkon, A. H., \& Guthman, J. (Eds.). (2017). The new food activism: 0 pposition, woperation and oollective action. O akland: University of California Press.

Anderson, L. (2006). Analytic autoethnography. Journal of C ontemporary E thnography, 35(4), 373-395. https:/ / doi.org/ 10.1177/ 0891241605280449

Ballamingie, P., \& Walker, S. M. L. (2013). Field of dreams: Just Food's proposal to create a community food and sustainable agriculture hub in O ttawa, O ntario. L ocal E nvironment, 18(5), 529-542. https:// doi.org/ 10.1080/ 13549839.2013.787975

Bartlett, L., \& Vavrus, F. (2017). Rethinking case study research: A comparative approach. New Y ork: Taylor \& Francis.

Bradley, K., Gregory M. M., Armstrong, J. A., Arthur, M. L., \& Porter, C. M. (2018). Graduate students bringing emotional rigor to the heart of community-university relations in Food D ignity. Journal of A griculture, F ood Systems, and C ommunity D evelopment, 8(Suppl. 1), 221-236. https:/ / doi.org/ 10.5304/ jafscd.2018.08A .003

Broad, G. M. (2016). M ore than just food: F ood justice and community change. O akland: University of California Press.

Campbell, M., \& G regor, F. (2004). M apping social relations: A primer in doing institutional ethnography. Walnut Creek, CA: AltaMira Press.

Cervero, R. M., \& Wilson, A. L. (2006). W orking the planning Table: N egotiating democratically for adult, continuing, and work plaœ education. San Francisco: Jossey-Bass.

Clandinin, D . J., \& Connelly, F. M. (2000). N arrative inquiry: Ex perience and story in qualitative research. San Francisco: JosseyBass.

Conk, S. J., \& Porter, C. M. (2016). Food gardeners' productivity in Laramie, Wyoming: More than a hobby. A merican Journal of Public H ealth, 106(5), 854v856. https:/ / doi.org/ 10.2105/ AJPH.2016.303108

Cox, R., Kneafsey, M., Holloway, L., D owler, E., \& Venn, L. (2014). G reater than the sum of parts? Unpacking ethics of care within a community supported agriculture scheme. In M. K. Goodman \& C. Sage (Eds.), F ood transgressions: Making sense of contemporary food politics (pp. 61-82). D orchester, UK: D orset Press.

Daftary-Steel, S. (2014). Building a great farmers mark et. Retrieved from https:/ / docs.wixstatic.com/ ugd/ c0c10a_b0f4bdd5d46542f2837eab59d9678b5a.pdf

D aftary-Steel, S. (2015). G rowing young leaders in E ast N ew Y ork. . Retrieved from https:/ / docs.wixstatic.com/ ugd/ c0c10a fb310ad357084e36939ded0b78c3b1c9.pdf

Daftary-Steel, S., \& G ervais, S. (Producer). (2015). ENYF Retrospective Case Study [Prezi presentation]. Retrieved from https:/ / prezi.com/ kixjpppdqbqz/ enyf-retrospective-case-study/ 
D aftary-Steel, S., Herrera, H., \& Porter, C. M. (2016). The unattainable trifecta of urban agriculture. Journal of A griculture, Food Systems, and Community D evelopment, 6(1), 19-33. https:/ / doi.org/ 10.5304/ jafscd.2015.061.014

D aftary-Steel, S., \& Noguera, N. (Producer). (2017). Urban agriculture with deep roots [Video]. Retrieved from https:/ / youtu.be/ awNaGirg2zg

Daftary-Steel, S., Porter, C. M., Gervais, S., Marshall, D ., \& D ., V. (2017). What grows in East New York: a case study of East New York Farms!, an examination of expectations of urban agriculture. In C. Bosso(Ed.), F eeding Cities: Improving L ocal F ood A coss, Security, and Sovereignty (pp. 95-112). New Y ork: Earthscan/ Routledge.

D aftary-Steel, S. (2018). Entering into a community-university collaboration: Reflections from East New Y ork Farms! Journal of A griculture, F ood Systems, and C ommunity D evelopment, 8(Suppl. 1), 5-7. https:// doi.org/ 10.5304/ jafscd.2018.08A.013

Denzin, N. K. (1978). Triangulation: A case for methodological evaluation and combination. Sociological Methods, 339357.

D enzin, N. K. (2006). Analytic autoethnography, or déjà vu all over again. Journal of C ontemporary E thnography, 35(4), 419428. https:/ / doi.org/ 10.1177/ 0891241606286985

Flyvbjerg, B. (2001). Mak ing social science matter: W hy social inquiry fails and how it can sucoed again. Cambridge, UK: Cambridge University Press.

Food D ignity. (2015). Paths to Food D ignity: D igital stories of personal journeys to food justice work. Retrieved from http:/ / www.tinyurl.com/ fooddignityplaylist

Foucault, M. (1972/ 1980). Power/ Knowledge: Selected interviews \& other writings, 1972- 1977 (C. Gordon, L. Marshall, J. Mepham, \& K. Soper, Trans.). New Y ork: Pantheon Books.

Foucault, M. (1981). The order of discourse. In R. Y oung (Ed.), U ntying the tex t: A post-structural anthology (pp. 48-78). Boston, MA: Routledge \& Kegan Paul.

Gaechter, L., \& Porter, C. M. (2018). "Ultimately about Dignity:" social movement frames used by collaborators in the Food Dignity action-research project. Journal of A griculture, F ood Systems, and Community D evelopment, 8(Suppl. 1), 147166. https:/ / doi.org/ 10.5304/ jafscd.2018.08A.004

Gerring, J. (2004). What is a case study and what is it good for? A merican Political Scienœ Review, 98(2), 341-354. https:// doi.org/ 10.1017/ S0003055404001182

Gregory, M. M., Leslie, T. W., \& D rinkwater, L. E. (2016). Agroecological and social characteristics of New York city community gardens: Contributions to urban food security, ecosystem services, and environmental education. U rban E cosystems, 19(2), 763-794. https:/ / doi.org/ 10.1007/ s11252-015-0505-1

Habermas, J. (1981/ 1984). Theory of communicative action: Reason and the rationalization of society (Vol. I). Boston, MA: Beacon Press.

Hallsworth, A., \& Wong, A. (2015). Urban gardening realities: The example case study of Portsmouth, England. International Journal on F ood System D ynamics, 6(1), 1-11. https:/ / doi.org/ 10.18461/ 1869-6945-1

Hargraves, M., D enning, C., BMA, DD F, ENYF, FLV, \& WCP (Producer). (2017). F ood D ignity Collaborative Pathway M odels. Retrieved from http:// www.fooddignity.org

Hargraves, M. (2018a). Learning from community-designed minigrant programs in the Food Dignity project. Journal of A griculture, Food Systems, and Community D evelopment, 8(Suppl. 1), 117-146. https:// doi.org/ 10.5304/ jafscd.2018.08A.007

Hargraves, M. (2018b). Introduction to the Food Dignity values statement. Journal of A griculture, F ood Systems, and Community D evelopment, 8(Suppl. 1), 33-35. https:/ / doi.org/ 10.5304/ jafscd.2018.08A.018

Hargraves, M., \& D enning, C. (2018). Visualizing expertise: Collaborative pathway modeling as a methodology for conveying community-driven strategies for change. Journal of A griculture, Food Systems, and Community D evelopment, 8(Suppl. 1), 101-115. https:/ / doi.org/ 10.5304/ jafscd.2018.08A.005

Hinrichs, C., \& Kremer, K. S. (2002). Social inclusion in a Midwest local food system project. Journal of Poverty, 6(1), 6590. https:// doi.org/ 10.1300/J134v06n01 04

Hou, J., Johnson, J., \& Lawson, L. J. (2009). G reening aities, growing communities: learning from Seattle's urban community gardens. Seattle: Washington University Press. 
Journal of Agriculture, Food Systems, and Community Development

Hunt, A. R. (2015). Civic engagement in food system governanœ: A comparative perspective of A merican and British local food movements. London: Routledge.

Kato, Y. (2013). Not just the price of food: Challenges of an urban agriculture organization in engaging local residents. Sociological Inquiry, 83(3), 369-391. https:/ / doi.org/ 10.1111/ soin.12008

King, T. (2005). The truth about stories: A native narrative. Minneapolis: University of Minnesota Press.

Kuhn, T. (1962). The structure of scientific revolutions. Chicago: University of Chicago Press

Lawson, L., D rake, L., \& Fitzgerald, N. (2016). Foregrounding community-building in community food security: A case study of the New Brunswick community farmers market and Esperanza Garden. In J. C. D awson \& A. Morales (Eds.), Cities of farmers: U rban agricultural practices and prooesses (pp. 141-158). Iowa City, IA: University of Iowa Press.

Lyotard, J. F. (1979/ 1984). The postmodern condition: A report on knowledge. (G. Bennington \& B. Massumi, Trans.). Minneapolis: University of Minnesota Press.

Maxwell, J. A. (2005). Q ualitative research design: A n interactive approach (2nd ed.). Thousand O aks, CA: Sage.

McCutcheon, P. (2011). Community food security "for us, by us": The Nation of Islam and the Pan African Orthodox Church. In A. H. Alkon \& J. Agyeman (Eds.), C ultivating food justice: Raœ, class, and sustainability (pp. 177-196). Cambridge, MA: MIT Press

McD onald, H. P. (2004). Radical axiology: A first philosophy of values. Amsterdam, Netherlands: Rodopi.

Meenar, M. R., \& Hoover, B. M. (2012). Community food security via urban agriculture: Understanding people, place, economy, and accessibility from a food justice perspective. Journal of A griaulture, Food Systems, and C ommunity D evelopment, 3(1), 143-160. https:/ / doi.org/ 10.5304/ jafscd.2012.031.013

Merriam, S. B. (1998). Q ualitative research and case study applications in education (2nd ed.). San Francisco: Jossey-Bass.

Neiderffer, M. (2018). Entering into a community-university collaboration: Reflections from Dig D eep Farms. Journal of A griculture, Food Systems, and C ommunity D evelopment, 8(Suppl. 1), 23- 25. https:/ / doi.org/ 10.5304/ jafscd.2018.08A.011

Passidomo, C. (2014). Whose right to (farm) the city? Race and food justice activism in post-Katrina New O rleans. A griculture and H uman V alues, 31(3), 385-396. https:/ / doi.org/ 10.1007/ s10460-014-9490-x

Poulsen, M. N. (2017). Cultivating citizenship, equity, and social inclusion? Putting civic agriculture into practice through urban farming. A griculture and H uman V alues, 34(1), 135-148. https:/ / doi.org/ 10.1007/ s10460-016-9699-y

Patton, M. Q. (2002). Q ualitative evaluation and research methods (3rd ed.). Thousand O aks, CA: Sage Publications.

Porter, C. M. (2013). Community action to prevent childhood obesity: Lessons from three US case studies. C hildhood 0 besity, 9 (2), 164-174. https:/ / doi.org/ 10.1089/ chi.2012.0018

Porter, C. M., Herrera, H., Marshall, D ., \& Woodsum, G. M. (2014). Shared voices, different worlds: Process and product in the Food Dignity action research project. $\mathrm{G}$ ateways: International Journal of $\mathrm{C}$ ommunity Research and E ngagement, 7(1), 116-128. https:/ / doi.org/ 10.5130/ ijcre.v7i1.3399

Porter, C. M. (2016). In a good way: ethics driven, evidence informed. Social Justice Research C enter blog, University of Wyoming. http:/ / www.uwyo.edu/ sjrc/ sjrc\%20blog/

Porter, C. M., McCrackin, P. G., \& Naschold, F. (2016). Minigrants for community health: A randomized controlled trial of their impact on family food gardening. Journal of Public $\mathrm{H}$ ealth M anagement and Pradiæ, 22(4), 379-386. https:// doi.org/ 10.1097/ phh.0000000000000359

Porter, C. M. (2018a). G rowing our own: Characterizing food production strategies with five U.S. community-based food justice organizations. Journal of A grialture, Food Systems, and Community D evelopment, 8(Suppl. 1), 167-185. https:/ / doi.org/ 10.5304/ jafscd.2018.08A.001

Porter, C. M. (2018b). What gardens grow: $O$ utcomes from home and community gardens supported by communitybased food justice organizations. Journal of A griaulture, F ood Systems, and C ommunity D evelopment, 8(Suppl. 1), 187-205. https:// doi.org/ 10.5304/ jafscd.2018.08A.002

Porter, C. M. \& Wechsler, A. (2018). Follow the money: Resource allocation and academic supremacy among community and university partners in Food D ignity. Journal of A griaulture, F ood Systems, and Community D evelopment, 8(Suppl. 1), 63-82. https:/ / doi.org/ 10.5304/ jafscd.2018.08A.006 
Ramírez, M. M. (2015). The elusive inclusive: Black food geographies and racialized food spaces. A ntipode, 47(3), 748769. https:/ / doi.org/ 10.1111/ anti.12131

Reynolds, K., \& Cohen, N. (2016). Beyond the kale: U rban agrialture and social justice adtivism in N ew Y ork City. Athens: University of Georgia Press.

Riessman, C. K. (1993). N arrative analysis. London: Sage.

Riley, T., \& Hawe, P. (2005). Researching practice: The methodological case for narrative inquiry. $\mathrm{H}$ ealth E ducation Research, 20 (2), 226-236. https:/ / doi.org/ 10.1093/ her/ cyg122

Robinson, J. A., Weissman, E., Adair, S., Potteiger, M., \& Villanueva, J. (2016). An oasis in the desert? The benefits and constraints of mobile markets operating in Syracuse, New Y ork food deserts. A griculture and H uman V alues, 33(4), 877-893. https:// doi.org/ 10.1007/ s10460-016-9680-9

Sandoval, C. (2000). M ethodology of the oppressed. Minneapolis: University of Minnesota Press.

Sbicca, J. (2012). G rowing food justice by planting an anti-oppression foundation: O pportunities and obstacles for a budding social movement. A griaulture and $\mathrm{H}$ uman V alues, 29(4), 455-466. https:/ / doi.org/ 10.1007/ s10460-0129363-0

Sbicca, J., \& Myers, J. S. (2017). Food justice racial projects: Fighting racial neoliberalism from the Bay to the Big Apple. E nvironmental Sociology, 3(1), 30-41. https:// doi.org/ 10.1080/ 23251042.2016.1227229

Sequeira, E. J. (2018). Entering into a community-university collaboration: Reflections from the Whole Community Project. Journal of A griaulture, F ood Systems, and Community D evelopment, 8(Suppl. 1), 9-11. https:// doi.org/ 10.5304/ jafscd.2018.08A.014

Sutter, V. J. (2018). Entering into a community-university collaboration: Reflections from Blue Mountain Associates. Journal of A griaulture, Food Systems, and C ommunity D evelopment 8(Suppl. 1), 13-15. https:// doi.org/ 10.5304/ jafscd.2018.08A.012

Smith, D. E. (2005). Institutional ethnography: A sociology for people. Oxford, UK: AltaMira Press.

Smith, L. T. (1999). D eolonizing methodologies: Research and indigenous peoples. London: Zed Books.

Stake, R. E. (1995). The art of case study research. Thousand O aks, CA: Sage Publications.

Thrasher, D . (2016). Fumbling for community in a Brooklyn community garden. In J. C. Dawson \& A. Morales (Eds.), Cities of farmers: U rban agriaultural practices and prooesses (pp. 159-176). Iowa City: University of Iowa Press.

Tuckman, B. W. (1965). D evelopmental sequence in small groups. Psychological Bulletin, 63(6), 384-399. https:/ / doi.org/ 10.1037/ h0022100

Urban, J., \& Trochim, W. (2009). The role of evaluation in research- practice integration working toward the "golden spike." A merican Journal of E valuation, 30(4), 538-553. https:/ / doi.org/ 10.1177/ 1098214009348327

U.S. D epartment of Agriculture National Institute of Food and Agriculture [USD A NIFA]. (2010). A griculture and F ood Research Initiative Competitive G rants Program, G lobal F ood Searity: FY 2010 request for applications. Washington, D.C.: National Institute of Food and Agriculture.

Venn, L., Kneafsey, M., Holloway, L., Cox, R., D owler, E., \& Tuomainen, H. (2006). Researching European 'alternative' food networks: Some methodological considerations. A rea, 38(3), 248-258. https:/ / doi.org/ 10.1111/ j.14754762.2006.00694.X

Ventura, S., \& Bailey, M. (Eds.). (2017). G ood food, strong ommunities: Promoting social justice through local and regional food systems. Iowa City: University of Iowa Press.

Vitiello, D., Grisso, J. A., Whiteside, K. L., \& Fischman, R. (2015). From commodity surplus to food justice: food banks and local agriculture in the United States. A grialture and $\mathrm{H}$ uman V alues, 32 (3), 419-430. https:/ / doi.org/ 10.1007/ s10460-014-9563-X

Wang, C., \& Burris, M. A. (1997). Photovoice: Concept, methodology, and use for participatory needs assessment. $\mathrm{H}$ ealth E ducation \& Behavior, 24(3), 369-387. https:// doi.org/ 10.1177/ 109019819702400309

Warshawsky, D. N. (2015). The devolution of urban food waste governance: Case study of food rescue in Los Angeles. Cities, 49(Supplement C), 26-34. https:/ / doi.org/ 10.1016/ j.cities.2015.06.006

Wechsler, A. (2017). O vercoming the Venn diagram: Learning to be a co-passionate navigator in community-based participatory research. Research for A ll, 1(1), 147-157. https:/ / doi.org/ 10.18546/ RFA.01.1.12 
Wekerle, G. R. (2004). Food justice movements: Policy, planning, and networks. Journal of Planning E ducation and Research, 23(4), 378-386. https:/ / doi.org/ 10.1177/ 0739456x04264886

White, J. T., \& Bunn, C. (2017). Growing in G lasgow: Innovative practices and emerging policy pathways for urban agriculture. L and U se Policy, 68, 334-344. https:/ / doi.org/ 10.1016/ j.landusepol.2017.07.056

White, M. M. (2011). D-Town Farm: African American Resistance to Food Insecurity and the Transformation of D etroit. E nvironmental Practice, 13(4), 406-417. https:/ / doi.org/ 10.1017/ S1466046611000408

Wilson, S. (2008). Research is œremony: Indigenous research methods. Black Point, Nova Scotia: Fernwood Publishing.

Woodsum, G. M. (2018). Entering into a community-university collaboration: Reflections from Feeding Laramie Valley. Journal of A griaulture, Food Systems, and C ommunity D evelopment, 8(Suppl. 1), 17-22. https:// doi.org/ 10.5304/ jafscd.2018.08A.017

Yazan, B. (2015). Three approaches to case study methods in education: Yin, Merriam, and Stake. The Q ualitative Report, 20(2), 134-152.

Y in, R. K. (2009). C ase study research: D esign and methods (4th ed.). Thousand O aks, CA: Sage Publications. 